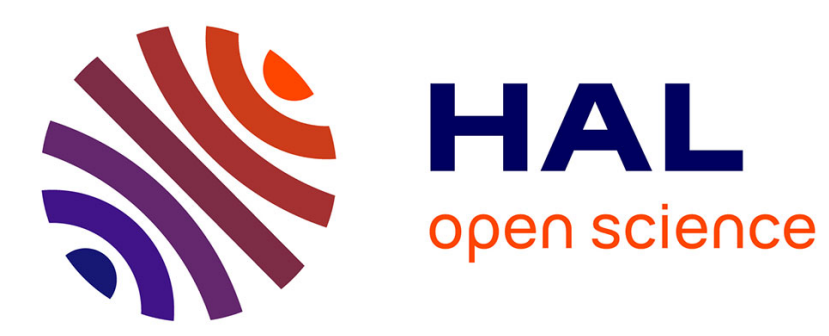

\title{
Changing One's First Name in France: a Fountain of Youth?
}

Baptiste Coulmont

\section{To cite this version:}

Baptiste Coulmont. Changing One's First Name in France: a Fountain of Youth?. Names: A Journal of Onomastics, 2014, 62 (3), pp.503-530. 10.1179/0027773814Z.00000000080 . halshs-01185061

\section{HAL Id: halshs-01185061 https://shs.hal.science/halshs-01185061}

Submitted on 19 Aug 2015

HAL is a multi-disciplinary open access archive for the deposit and dissemination of scientific research documents, whether they are published or not. The documents may come from teaching and research institutions in France or abroad, or from public or private research centers.
L'archive ouverte pluridisciplinaire HAL, est destinée au dépôt et à la diffusion de documents scientifiques de niveau recherche, publiés ou non, émanant des établissements d'enseignement et de recherche français ou étrangers, des laboratoires publics ou privés. 


\title{
Changing One's First Name in France: a Fountain of Youth?
}

\section{Baptiste Coulmont}

Université Paris 8 Vincennes-Saint-Denis, France

\begin{abstract}
A change of name is a change of identity. Many studies have focused on changes in ethnic identity, because those who change their name are often descendants of migrants or migrants themselves. This article focuses on first name changes in France. It shows that those who change their first name are indeed overwhelmingly the descendants of migrants, but that their identity change is multidimensional. Changing one's first name is also a way to get a younger first name.
\end{abstract}

Keywords: age, class, law, identity, ethnicity, sociology, France 


\section{Changing One's First Name in France: a Fountain of Youth?}

\section{Introduction}

Name changes are good examples of identity changes. Sociologists such as Erving Goffman and Anselm Strauss have elaborated on the management of spoiled social identities (Goffman 1975; Strauss 1959) and discussed the use of pseudonyms, nicknames, and fake names. Articles on name changes by legal scholars focus on issues of individual legal identity in the context of the state's increasing control over identification: Heymann and Julia Shear Kushner (Shear Kushner 2009; Heymann 2011; Heymann 2012) show that legal scholars debate the "right to control one's name" vis-à-vis the state's right to identify its citizens.

Empirical studies on name changes focus on a central theme: migrants and descendants of migrants change their names, and this is a way to modify one's ethnic identity.

In South Africa, for example, De Klerk studied name changes that took place as a consequence of acculturation and assimilation following migration to cities (De Klerk and Lagonikos 2004), with Black South Africans taking "English" first names when they had “African" first names. In the United States Broom and his colleagues, and then Maass and Scherr (Broom, Beem, and Harris 1955; Scherr 1986; Maass 1958), also found that migrants and descendants of migrants were overrepresented in petitions for name changes. Two other articles (Drury and McCarthy 1980; Kang 1971) focus on name changes among foreign students (Chinese students in the United States and US students in Copenhagen), and show that students 
who change their names "are more fully socialized into the host society than those who do not" (Kang 1971, 405) and "move toward the periphery of their own ethnic community" (Kang 1971, 411). In the same way, Laurie Duthie's article on Chinese business professionals explains changes of personal name as a way for the business community to "secur[e] a place within national discourse of modernization and globalization. In doing so, business professionals reaffirm the state's goal of participating in the global market on its own terms and as an equal to the West" (Duthie 2007, 75). In addition, Duthie shows that Chinese business professionals try to choose a name that is neither too common nor too rare (these are the same elements that give rise to fashions in baby names) (Duthie 2007). The recent interest of Swedish sociologists and economists in name changes is also due in large part to the fact that Sweden is increasingly becoming a country of immigration (Arai and Skogman Thoursie 2009; Bursell 2012; Khosravi 2012): name change is a form of "pragmatic assimilation" used by migrants to cope with possible discrimination in the marketplace and the workplace.

This theme is also central in France. Masure and Lapierre (Masure 2008; Lapierre 1993; Lapierre 2006; Lapierre 2012) have studied the process of "francisation" ("Frenchification"), whereby new citizens can translate their names into French or take new French names when they become French citizens. This phenomenon is also mentioned in Jacob and Horn's study of published name changes in France (Jacob and Horn 1998).

My article differs from these previous studies in two main respects. First, I focus on first name changes, and I show that they are not similar to last name changes. Second, I propose to 
look beyond the mainstream of explicit ethnic identity changes, to consider some of the other dimensions involved in changing a first name.

Most previous studies exclusively deal with family names, or else consider first names and family names to be similar, without differentiating between the two. In many countries, the same court or administrative procedure is used to change one's last or one's first name, and this may explain why family names and first names tend to be studied together. This is not the case in France, however, where changing one's family name and changing one's first name are two very distinct procedures. Changing one's last name involves a centralized administrative procedure (it is done by decree, not by a court ruling), whereas changing one's first name involves a local tribunal and a judge.

The existence of two separate procedures suggests that family names and first names have different purposes and are used differently. In France, family names are inherited and cannot be invented, whereas first names are chosen for the child by the parents, and may be new inventions (for a summary of the French law on first names, see Willingham-McLain 1997). A large body of sociological and historical scholarship (Lieberson 2000; Bozon 1987) has shown that today's first names, in France and in the US, can be inherited, but they are increasingly being chosen from first names not already given within the family. Surnames aggregate to the family; first names individualize within the family.

First names have several secondary characteristics that are not present in last names. First names exhibit fashion dynamics, because they are chosen by parents (Lieberson 2000). While 
there are no fashions in family names, first names are subject to fads and neglect. First names are consequently generational: names given to previous generations are seldom given to later ones. In France this fashion can be partly explained by a class-based temporal dynamic (Besnard and Grange 1993; Besnard and Desplanques 1999). The relationship between social class and first names is a dynamic one: often (at least in France), popular names are first given to babies by upper-class parents, who are (consciously or not) looking for a name that is not associated with lower-class babies. But the lower classes soon adopt some of those new names (Desplanques 1986). As signs of distinction, names rapidly lose their value. What had been deemed upper class in 1970 was seen as lower class in 1990.

Lastly, first names in France are gendered. Family names, which are transmitted patrilineally or matrilineally, are not gendered. If Julia as a first name is a girl's name, Julia as a last name may be the name of a man or a woman.

Since first names are indicators not only of ethnicity, but also of gender, age and social origin, it is possible that a change of first name will give new indications, besides a change in ethnicity. My hypothesis is that first name changes are complex and multidimensional identity changes, beyond assimilation to a mainstream ethnic identity.

This article focuses on first name changes in France. I will show that first name changers are indeed largely migrants and descendants of migrants, even if the option to change one's name is open to all citizens. I will also show that when people change their first name, they almost always do so in a systematic way: they take an objectively "younger" first name. 


\section{Research setting}

In France, in order to legally change one's first name, one has to convince a judge that one has good reason to be called by a first name not given in the "acte de naissance" (official birth certificate). The judge in question will be a "family affairs judge" in a "tribunal de grande instance" (a local lower court); these judges specialize in divorce, adoption and "family" cases. By contrast, in order to change one's family name, one has to enter a more complex and centralized administrative procedure at an office of the Ministry of Justice in Paris (Lapierre 2006). This means that it is much easier to change a first name than to change a family name, since court judgments have become increasingly liberal, whereas administrative rules continue to be restrictive.

In order to change a first name, one needs to hire a lawyer. This lawyer will write a petition or "request" ("requête") in which the legal reasons for the change will be stated. The lawyer will also add to this request two sets of documents: "attestations" (written testimonies from relatives or friends), and papers such as cards, bills, checks, letters, e-mails, postcards, or anything on which the requested first name appears. These documents are filed with the local court, and a "procureur" (state attorney) will then give a written opinion ("favorable", "neutral", "reserved" or "opposed"). Then a court hearing will be scheduled, during which the lawyer and the applicant will verbally explain their request. After hearing the reasons, the "procureur" will give a new opinion. The judge usually takes some time before writing the judgment. This procedure has been in place since 1993 (Loi du 8 janvier 1993). 
Out of nearly 65 million residents in France (and 800,000 births each year), very few people are sufficiently unhappy to wish to change their given names, even though the court procedure is quite straightforward and not very expensive. Just under 3,000 requests have been filed each year for the past 15 years. Around $7 \%$ of petitions for name change are rejected; onethird of these rejected petitions are then accepted on appeal. In a social world where achieved status is valued, one's atomic marker of identity, one's first name, is still ascribed at birth.

I have had full access to four courts (two of the largest such courts in France, and two smaller ones). At each of these courts, I have been able to observe closed hearings and to read the applicants' files. Relevant information (such as first names, year of birth, occupation, place of birth, and court decision) was entered into a database. I have supplemented this material with formal and informal interviews with "procureurs", judges, "greffières" (court clerks), and lawyers. In these courts, I have consulted a total of 541 files and judgments from between 2010 and 2012. A complementary study was also conducted on more than 250 published or indexed appeals over court decisions on first name changes.

\section{A consequence of migration}

Applicants constitute a diverse group. In the files consulted, $49 \%$ of the applicants are women, 51\% men. Younger applicants are slightly more likely to be men, older applicants more likely to be women. Their ages span from 0 to more than 80 years old. Parents are requesting a change to their child's first name in $22 \%$ of the files (consent of the child is required when the child is deemed old enough, but minors always need to be represented by their parents or a tutor). 
Applicants often have one or two foreign-born parents: $80 \%$ have at least one parent born outside of France. Their first names were chosen by parents whose cultural references and naming habits were probably "located" in a country of origin.

\section{TABLE 1 HERE}

But these applicants were very often born in France: more than two-thirds of them. As Broom and his colleagues remarked (Broom, Beem, and Harris 1955), first name changes are made by the descendants of migrants more often than by migrants themselves. This may be due to a self-selection effect: it must be noted that nearly all first name changers are French citizens. Foreigners who want to change their first name are very few, and they can only legally change their first name in France if their country of citizenship also has laws allowing name change.

\section{TABLE 2 HERE}

Taken as a whole, this population of name-changers seems to be dealing with the consequences of migration. The foreign-born and their descendants are indeed overrepresented among name-changers compared with the general population in the regions, departments or cities where the tribunals are located.

In more than $50 \%$ of written requests, the lawyer and the applicant make an explicit link between first name and national or ethnic identity. A first name change is presented as a way to resolve a tension between the group to which the changers are assigned and the group against which they compare themselves (their reference group). As the following excerpt shows, these links between name and national identity are very explicitly put forward by lawyers: 
My client is called Rachid. Mr. $\mathrm{K}^{*}$ wishes to modify this first name in order to be fully assimilated, and he wishes to highlight the following reasons. $1 . \mathrm{Mr} . \mathrm{K} *$ is not attached to his first name; Mr. $\mathrm{K}^{*}$ was born in France and has always been a French resident; Mr. $\mathrm{K}^{*}$ is registered as a ward of state. He does not know his parents. His father never recognized him as his own and never saw him. He has no memory of his mother. 2. Mr. K* wishes especially to be able to demonstrate his complete assimilation to French society with a French first name that he can use in his occupation. Mr. $\mathrm{K}^{*}$ is 26 years old. He has a professional chef's diploma, and specializes in pastries and baking. Mr. K* works in wellknown Parisian restaurants. He wishes to have a French-sounding first name so that his first name will not hinder him in the development of a successful career. (Excerpt from a "requête" filed in 2009. The applicant was born in France to an Algerian-born mother. ${ }^{\mathrm{i}}$ )

However, many requests are filed by applicants who want to exchange a first name that might sound "foreign" for another first name that might also sound "foreign" (e.g. Nabila to Fatima), or to move from a traditional Catholic saint's name to an equally Catholic or French sounding-name (e.g. Martin to Sébastien).

\section{Beyond ethnicity}

Only a small proportion of applicants revealed in their request or in other documents that they had changed - or wanted to change - their family name. This is surprising, because the courts have always recognized a change of family name as a favorable element in requests for a change of first name. Moreover, if factors such as national origin or perceived ethnicity are 
something that the applicants want to change, those characteristics are also attached to surnames. My hypothesis is therefore that changing their first name gives applicants something that they would not get by changing their family name.

\section{Gendered mobility}

French first names are gendered, and people are rarely given an androgynous first name (concerning France, see Coulmont 2011; concerning the US, see Lieberson, Dumais, and Baumann 2000). In France, people labeled "transsexuals" frequently use other legal alternatives (after surgery and an official change of sex on their birth certificate, they can ask for a "rectification" of the first names given on the birth certificate), and there were very few transsexuals represented in the courts I studied (Courduriès 2008). As a consequence, only a small number of applicants claimed to have a first name of the wrong gender; but when they did so, they explicitly used the "wrong gender" line of argument in order to get a new name.

\section{Social mobility}

A large part of the sociological scholarship on first names deals with the idea that, as manifestations of personal taste, first names are used to establish and maintain class distinctions and class boundaries. However, this marking is done by parents, to a child who later may not be part of the same social group as them. Could it be that changing one's first name is a way to distance oneself from the social class of one's parents, a social class embedded in the first name that they chose? The family setting should be taken into account: as Nagata has shown, name 
changes in $19^{\text {th }}$-century Japan were "usually prompted by events that affected the relative status of the name changer within his family" (Nagata 1999, 335).

Unfortunately, administrative and court files do not give coherent information on the social origins of people who want to change their names. The father's and mother's occupations are often missing. When we do have information on both the applicant and his/her father (in 247 files out of 541), the population appears to be an upwardly mobile one: $36 \%$ of fathers were bluecollar workers, while only $3 \%$ of the applicants are blue-collar workers. Moreover, it seems that many of the applicants have experienced the consequences of significant geographical mobility, and that their (or their parents') social position in France is very different from that of their parents in their country of origin. But this argument is very rarely used in the files; even when typical working-class first names (such as Johnny or Kevin) are being abandoned, the class mobility argument is not explicit.

\section{Generational mobility}

If it is impossible to conclude from the files that first name changes are a consequence of upward class mobility, it is still possible to explore the temporal dynamics of the abandoned first name and the new one.

I will use here three related variables. The first is the date of birth of the applicant. The other two are the time-frequency distributions of the two first names (the original first name and the wished-for name). These time-frequency distributions are available in the "First name File" 
created by the French National Institute of Statistics and Economic Studies. ${ }^{\text {ii }}$ This "First name File" covers the period 1900-2008.

\section{FIGURE 1 HERE}

Figure 1 needs some explanation. It synthesizes a request filed by a woman named Fabienne. She was born in 1977 (indicated as a circle on the figure), at a time when her first name was on the decline: it had peaked in 1965. In 2010, she filed a petition for a change of first name. She and her lawyer wrote that her new first name should be Florine. Compared to Fabienne, Florine is a younger first name, whose distribution peaked in 1998.

The year of the peak is taken as a proxy for the first name's "mean age": it is then easy to compare abandoned and new first names. In the Fabienne-to-Florine case, the applicant is looking for a first name that is 33 years younger than the one she is getting rid of.

The first names of the 541 applicants were compared using the same method. Problems arise when first names are too unusual to be included in the "First name File": therefore 388 pairs of first names have been compared out of 541 files.

$72 \%$ of applicants wish to take a name that is more recent (that is, a name whose "peak" is more recent than that of their previous name). These applicants request a name that is 25 years younger (median: 24, mean: 30). They take a name that they could have given to their child.

In order to appraise this method, the same exercise was carried out with 259 appeal court decisions on first name changes between 1985 and 2011. ${ }^{\text {iii }}$ Out of these 259 decisions, 171 pairs 
of first names were usable (in many cases, the first names were too unusual). $68 \%$ of these applicants had chosen a younger first name (the mean difference is 28 years younger, the median is 24). As with lower-court cases, there was no difference between men and women in their desire for younger first names.

This "peak comparison" method also reveals that $28 \%$ of the lower-court applicants (and $32 \%$ of the appeal court applicants) seem to want to take an older name. These names are specific: they are names such as Paul, Armand or Louis, whose frequency peak was at the very

beginning of the $20^{\text {th }}$ century, but which are currently regaining popularity and increasingly being given to babies. Thus in subjective assessments they could all be seen as "younger" names than those given in the middle of the $20^{\text {th }}$ century, such as Philippe or Denis.

\section{Discussion}

A first name change appears to be a multidimensional identity change. It involves descendants of migrants who are often claiming an ethnic or national identity as the basis of their request. But those same people are also "mobile" social actors whose current social position is different from that of their (foreign-born) parents.

These "changers" take a first name that has age-related significations. First they take a first name that implicitly signifies their belonging to a younger generation (compared to the generation implied by their previous first name). Changing one's first name brings a hidden benefit that is otherwise very hard to get, even with moisturizers, regular exercise, and healthy food - it allows one to be perceived as younger than before. Moreover, people often take a first 
name that is "younger" than they are (and men and women show similar behavior): its "peak" is located after their date of birth.

Second, these "changers" often take a name that was not common when they were born, but which became popular after they were born. They "surf” on the class dynamic wave: implicitly, their new first name (compared with their date of birth) signifies that their parents were perhaps more upper-class than were the parents who actually chose their abandoned first name.

But neither the applicants nor their lawyers explicitly state in the files that they want a “younger" name. Abandoned names are almost never described as old-fashioned. iv Taking a younger name is not an expressed subjective desire, and it is rarely the explicit reason put forward by the applicant. It is the objective result of statistical comparisons between the abandoned names and the new ones.

\section{Conclusion}

As Claude Lévi-Strauss put it radically in The Savage Mind: “One [...] never names: one classes someone else if the name is given to him in virtue of his characteristics and one classes oneself if, in the belief that one need not follow a rule, one names someone else 'freely', that is, in virtue of characteristics of one's own" (Lévi-Strauss 1966, 181).

In a change of one's own first name, one names oneself in virtue of one's characteristics; one classes oneself even more radically than when one names someone else. This classificatory 
act is not always a play on wished-for ethnicity or national identity. My initial hypothesis is validated: a change of first name is a move along several dimensions, not only ethnic or national ones. It is often a relational play between an older name and a younger one - a play on social origin and social position, on ascribed identity and achieved status. That is why changing a family name and changing a first name are different social acts. As Bromberger, a French anthropologist, put it, changing one's first name is akin to "déjouer l'usure du temps", finding a way to escape the ravages of time (Bromberger 1982,110). But when people change a name for ethnic reasons, they explicitly say so: they want "assimilation" or to feel closer to their parents' country of origin. On the other hand, a desire for a "younger" name is not explicitly stated, and the phenomenon would have remained invisible without statistical analysis of the first names themselves.

Further studies on first name change should be conducted in order to replicate these findings and to identify similar behavior in other settings, so as to better understand the interplay between national origin, first name, and the choice of a more or less fashionable first name.

\section{Acknowledgments}

My thanks go to Ariane Zambiras, François Briatte, Etienne Ollion and Merl Storr; and also to Uwe Russ, who suggested the title, and to Jürgen Gerhards, whose direct comments contributed to this paper. The study was made possible by a grant from the French Ministry of Justice's research center, the Mission de Recherche Droit et Justice. 


\section{Bibliography}

Arai, Mahmood \& Peter Skogman Thoursie. 2009. "Renouncing Personal Names: An Empirical Examination of Surname Change and Earnings.” Journal of Labor Economics 27(1): 12747.

Besnard, Philippe \& Guy Desplanques. 1999. "Les catégories socioprofessionnelles à l'épreuve de la stratification temporelle des goûts." Revue Française de Sociologie 40(1): 97-109.

Besnard, Philippe \& Cyril Grange. 1993. "La fin de la diffusion verticale des goûts? (Prénoms de l'élite et du vulgum)." L'Année Sociologique 43: 269-94.

Bozon, Michel. 1987. "Histoire et sociologie d'un bien symbolique, le prénom." Population 42(1): 83-98.

Bromberger, Christian. 1982. "Pour une analyse anthropologique des noms de personnes." Langages 66: 103-24.

Broom, Leonard, Helen P. Beem \& Virginia Harris. 1955. "Characteristics of 1,107 Petitioners for Change of Name." American Sociological Review 20(1): 33-39.

Bursell, Moa. 2012. "Name Change and Destigmatization Among Middle Eastern Immigrants in Sweden.” Ethnic and Racial Studies 35(3): 471-87.

Coulmont, Baptiste. 2011. Sociologie des prénoms. Paris: La Découverte. 
Courduriès, Jérôme. 2008. “《 Re-naître » à l’autre sexe. Le changement de prénom des transsexuels à l'état-civil." États civils en questions. Papiers, identités, sentiment de soi. Ed. Agnès Fine. Paris: Editions du CTHS, 225-42.

De Klerk, Vivian \& Irene Lagonikos. 2004. "First name Changes in South Africa: The Swing of the Pendulum." International Journal for the Sociology of Language 170: 59-80.

Desplanques, Guy. 1986. "Les enfants de Michel et Martine Dupont s'appellent Nicolas et Céline." Économie et Statistique 184: 63-83.

Drury, Darrel W \& John D McCarthy. 1980. "The Social Psychology of Name Change: Reflections on a Serendipitous Discovery." Social Psychology Quarterly 43(3): 310-20.

Duthie, Laurie. 2007. "Western Names for Chinese Identities: The Acquisition and Use of Western Personal Names Among Chinese Business Professionals in Foreign-Invested Corporations." Asian Anthropology 6(1): 53-80.

Goffman, Erving. 1975. Stigma : Notes on the Management of Spoiled Identity. Englewood Cliffs: Prentice-Hall

Heymann, Laura A. 2011. "Naming, Identity, and Trademark Law." Indiana Law Journal 86: $381-445$.

—. 2012. "A Name I Call Myself: Creativity and Naming." UC Irvine Law Review 2(2): $585-625$.

Jacob, James E. \& Pierre L. Horn. 1998. “Comment Vous Appelez-vous?: Why the French Change Their Names." Names 46(1): 3-28. 
Kang, Tai S. 1971. "Name Change and Acculturation: Chinese Students on an American Campus." The Pacific Sociological Review 14(4): 403-12.

Khosravi, Shahram. 2012. "White masks/Muslim Names: Immigrants and Name-changing in Sweden.” Race \& Class 53(3): 65-80.

Lapierre, Nicole. 1993. "La francisation des noms.” Ethnologie Française 23(2): 207-14.

- 2006. Changer de nom. [first edition 1995]. Paris: Gallimard.

—. 2012. "Fortunes et infortunes de la nomination." La Lettre de l'enfance et de l'adolescence 87: 51-58.

Lévi-Strauss, Claude. 1966. The Savage Mind. The Nature of Human Society Series. London: Weidenfeld \& Nicolson.

Lieberson, Stanley. 2000. A Matter of Taste. How Names, Fashions, and Culture Change. New Haven: Yale University Press.

Lieberson, Stanley, Susan Dumais \& Shyon Baumann. 2000. “The Instability of Androgynous Names: The Symbolic Maintenance of Gender Boundaries.” The American Journal of Sociology 105(5): 1249-87.

Maass, Ernest. 1958. “Integration and Name-changing Among Jewish Refugees from Central Europe in the United States." Names 6(3): 129-71.

Masure, François. 2008. "Des noms français ? Naturalisation et changement de nom.” États civils en questions. Papiers, identités, sentiment de soi. Ed. Agnès Fine. Paris: Éditions du CTHS, 245-73. 
Nagata, Mary Louise. 1999. "Why Did You Change Your Name? Name Changing Patterns and the Life Course in Early Modern Japan.” The History of the Family 4(3): 315-38.

Scherr, Arthur. 1986. "Change-of-Name Petitions of the New York Courts : An Untapped Source in Historical Onomastics.” Names 34(3): 284-302.

Shear Kushner, Julia. 2009. "The Right to Control One's Name.” UCLA Law Review 57: 313-64.

Strauss, Anselm. 1959. Mirrors and Masks : the search for identity. Glencoe: Free Press

Willingham-McLain, Laurel. 1997. “Arrosoir, Oui, Manhattan, Non: Naming and the Law in France.” Names 45(3): 185-202.

\section{Notes on Contributor :}

Baptiste Coulmont is Associate Professor of sociology at the Université Paris 8 VincennesSaint-Denis. He is the author of Sociologie des prénoms (Paris, Éditions La Découverte, 2011). Correspondance to Baptiste Coulmont, CRESPPA-CSU, CNRS, 59-61 rue Pouchet, F-75017 Paris, France, coulmont@ens.fr 
TABLE 1

\begin{tabular}{|lll|}
\hline & Foreign-born mother & Mother born in France \\
\hline Foreign-born father & $62.5 \%$ & $11.9 \%$ \\
\hline Father born in France & $6.1 \%$ & $19.5 \%$ \\
\hline
\end{tabular}

Table 1: Parents' place of birth $(\mathrm{N}=430)$ 


\section{TABLE 2}

\begin{tabular}{|ll|}
\hline Name-changer's place of birth & Percentage \\
\hline Outside of France & $32 \%$ \\
\hline In France & $68 \%$ \\
\hline
\end{tabular}

Table 2: Applicants' place of birth $(\mathrm{N}=541)$ 


\section{FIGURE 1}

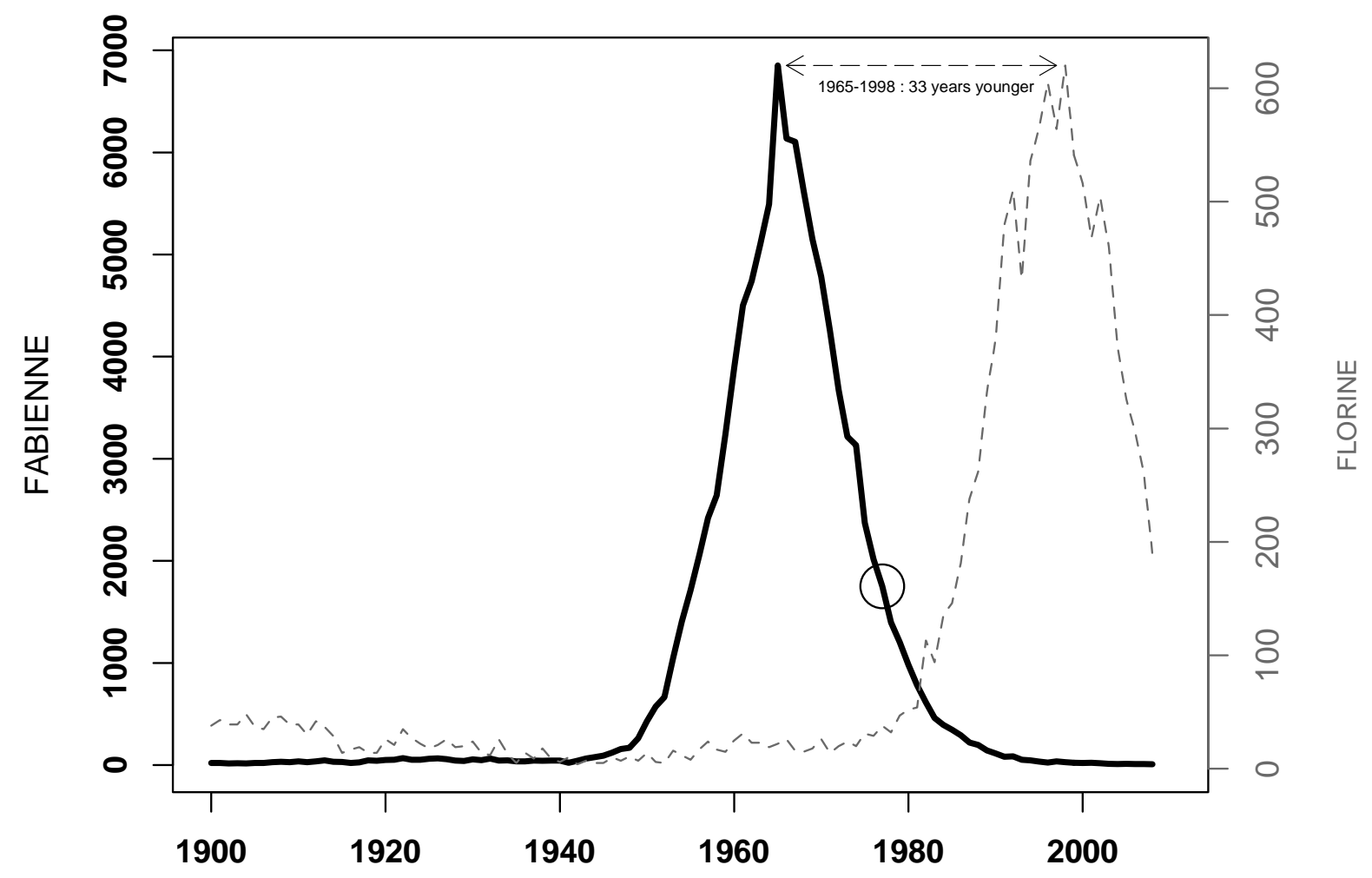

Figure 1: Fabienne, born in 1977, wishes to be called Florine

\footnotetext{
${ }^{\mathrm{i}}$ Original French text : "Le requérant porte le prénom de Rachid. M. K souhaite modifier ce prénom dans un souci de parfaite intégration, et souhaite souligner plus particulièrement les raisons suivantes. 1 - M. K n'a aucune attache particulière à son prénom; M. K est né en France et y a toujours résidé; $M . K$ a été admis en qualité de pupille de l'État. Il ne connait pas ses
} 
parents. Son père ne l'a jamais reconnu et ne s'est jamais manifesté. Il n'a aucun souvenir de sa mère. 2- M. K souhaite tout particulièrement pouvoir faire valoir sa complète intégration à la société française à travers un prénom français dans le domaine professionnel. M. K a 26 ans. Il a un CAP cuisine, complété par une formation en pâtisserie. $M$. K a travaillé dans des restaurants parisiens réputés. Il souhaite aujourd'hui porter un prénom à consonance française afin d'éviter que son prénom ne constitue un frein à une parfaite évolution de carrière."

${ }^{\text {ii }}$ Fichier des prénoms - Edition 2009 (2009, INSEE) Obtained through the Centre Quêtelet, ref. lil-0496.

iii These decisions were gathered from the Lexis-Nexis database (French court jurisprudence). ${ }^{\text {iv }}$ First names ending in "-ette" (e.g. Claudette and Josette) are the exception. These names are explicitly described as old-fashioned, and applicants in such cases do write that they want a younger-sounding name. 